\title{
GREEN SYNTHESIS NANOPARTIKEL ZnO MENGGUNAKAN MEDIA EKSTRAK DAUN TIN (Ficus carica Linn)
}

\author{
Iwan Syahjoko Saputra ${ }^{1}$, Siti Suhartati ${ }^{1}$, Yoki Yulizar$^{2}$, Sudirman $^{3}$ \\ 1)Akademi Kimia Analis Caraka Nusantara \\ Jl. Tugu Raya Komplek Timah, Cimanggis, Depok \\ 2)Universitas Indonesia \\ Kampus Baru UI, Depok \\ 3)Badan Tenaga Nuklir Nasional \\ Kawasan Puspitek, Serpong, Tanggerang Selatan \\ E-mail: iwan28chemistry@gmail.com
}

3 September 2019; 20 September 2019; 19 Februari 2020

\begin{abstract}
ABSTRAK
GREEN SYNTHESIS NANOPARTIKEL ZnO MENGGUNAKAN MEDIA EKSTRAK DAUN TIN (Ficus carica Linn). Tujuan penelitian ini adalah sintesis nanopartikel $\mathrm{ZnO}$ menggunakan metode green synthesis dengan memanfaatkan ekstrak daun tin (Ficus carica Linn) sebagai media. Gugus aktif yang terkandung dalam ekstrak daun tin berperan sebagai media sekaligus sumber basa alami dalam sintesis nanopartikel $\mathrm{ZnO}$ dan berpengaruh terhadap sifat optik, bentuk morfologi serta karakteristik nanopartikel ZnO. Hasil karakterisasi nanopartikel $\mathrm{ZnO}$ menggunakan Spektrofotometer UV-Vis menunjukkan puncak serapan pada panjang gelombang $260 \mathrm{~nm}$ dengan nilai absorbansi 0,6. Hasil UV-Vis DRS menunjukkan nilai bandgap nanopartikel ZnO sebesar 3,32 eV dan hasil karakterisasi XRD menunjukkan tiga puncak spesifik kristalinitas nanopartikel ZnO yaitu pada 2 teta: $30.71^{0}, 33.36^{\circ}$, dan $37.20^{\circ}$ dengan ukuran kristal $15,9 \mathrm{~nm}$. FTIR menunjukkan adanya vibrasi $\mathrm{ZnO}$ pada bilangan gelombang $492 \mathrm{~cm}^{-1}$ dan puncak serapan gugus fungsi $-\mathrm{OH}$ pada bilangan gelombang 3501 $\mathrm{cm}^{-1}$, $-\mathrm{C}=\mathrm{O}$ pada bilangan gelombang $2490 \mathrm{~cm}^{-1}, \mathrm{C}-\mathrm{O}-\mathrm{H}$ pada $1397 \mathrm{~cm}^{-1}$, dan gugus fungsi amina pada $913 \mathrm{~cm}$ 1. Hal ini mengindikasikan bahwa dalam ekstrak daun tin terdapat metabolit sekunder yang dapat berperan sebagai media dalam pembentukan nanopartikel ZnO. Hasil SEM-EDS menunjukkan bentuk morfologi nanopartikel $\mathrm{ZnO}$ berbentuk seperti kapas dengan perbandingan massa unsur $\mathrm{Zn}$ dan O adalah $30,24 \%$ dan $69,76 \%$. Hasil PSA dan PZC menunjukkan nanopartikel ZnO memiliki nilai PDI sebesar 0,739 dan distribusi rata-rata ukuran partikel sebesar 49,62 dengan nilai zeta potensial $-23 \mathrm{mV}$.
\end{abstract}

Kata Kunci: Green synthesis, Nanopartikel ZnO, Ficus carica Linn

\begin{abstract}
GREEN SYNTHESIS OF ZnO NANOPARTICLES USING FICUS CARICA L LEAF EXTRACT. The purpose of this study is to synthesize ZnO nanoparticles using green synthesis method by utilizing Ficus carica Linn leaf extract. The functional group contained in Ficus carica Linn leaf extract acts as a medium as well as a natural base source in the synthesis of $\mathrm{ZnO}$ nanoparticles. It will also affect the optical properties, morphological shape and characteristics of $\mathrm{ZnO}$ nanoparticles. The results of $\mathrm{ZnO}$ nanoparticles using UV-Vis spectrophotometer showed the absorption peak at a wavelength of $260 \mathrm{~nm}$ with an absorbance value of 0.6. The UV-Vis DRS showed the ZnO nanoparticle bandgap value of $3.32 \mathrm{eV}$ and the XRD characterization results showed three specific peaks of $\mathrm{ZnO}$ nanoparticles at $30.71^{\circ}, 33.36^{\circ}$, and $37.20^{\circ}$ with a crystallite size of $15.9 \mathrm{~nm}$. FTIR shows the existence of $\mathrm{ZnO}$ vibrations at $492 \mathrm{~cm}^{-1}$ and the absorption peak of the $-\mathrm{OH}$ function group at $3501 \mathrm{~cm}^{-1}$, $\mathrm{C}=\mathrm{O}$ at $2490 \mathrm{~cm}^{-1}, \mathrm{C}-\mathrm{O}-\mathrm{H}$ at $1397 \mathrm{~cm}^{-1}$, and amine functional groups at $913 \mathrm{~cm}^{-1}$. This indicates that in the Ficus carica Linn leaf extract there are secondary metabolites that can act as a medium in the formation of $\mathrm{ZnO}$ nanoparticles. The results of SEM-EDS showed the morphology of ZnO nanoparticles with cotton-like shape and a composition of $30.24 \%$ and $69.76 \%$ for $Z n$ and O, respectively. Results of PSA and PZC showed that ZnO nanoparticles have a PDI value of 0.739 and an average particle size distribution of 49.62 with a potential zeta value of $-23 \mathrm{mV}$.
\end{abstract}

Keywords: Green Synthesis, ZnO Nanoparticles, Ficus carica Linn 


\section{PENDAHULUAN}

Seng oksida ( $\mathrm{ZnO})$ merupakan material anorganik berwujud bubuk yang sukar larut dalam air. Pada berbagai produk dan material, $\mathrm{ZnO}$ banyak digunakan sebagai bahan aditif. ZnO merupakan material semikonduktor tipe II dan VI yang memiliki celah pita (band gap) lebar yaitu 3,37 eV dan energi ikatan sebesar $60 \mathrm{MeV}$ (Parra dan Haque, 2014). Padatan ZnO memiliki tiga bentuk kristal yaitu hexagonal wurtzite, cubic zincblende, dan cubic rocksalt (jarang teramati). Bentuk wurtzite pada $\mathrm{ZnO}$ merupakan struktur kristal yang paling stabil pada suhu kamar. $\mathrm{ZnO}$ memiliki sifat yang unggul dan dapat diaplikasikan dalam bidang optik, optoelektronik. Serbuk $\mathrm{ZnO}$ juga dapat digunakan sebagai bahan aditif dalam pembuatan keramik, plastik, semen, kaca, karet dan pelumas. Meski ZnO terdapat pada kerak bumi dalam bentuk mineral yang dinamakan zincite, namun pada umumnya produksi $\mathrm{ZnO}$ secara komersial dilakukan secara sintesis. ZnO memiliki tiga bentuk kristal berdimensi satu (1D) seperti rod, tube, wire, dan nail; berdimensi dua seperti sheet, hexagon, tower, dan comb, berdimensi tiga (3 D) seperti flower. Kelebihan $\mathrm{ZnO}$ adalah salah satu senyawa oksida yang memiliki celah pita lebar dibanding oksida-oksida logam yang lain (Zheng et al., 2001). Adanya nilai celah pita yang lebar pada senyawa $\mathrm{ZnO}$, maka $\mathrm{ZnO}$ dapat disintesis, dimodifikasi dan banyak diaplikasikan oleh para peneliti dalam bidang semikonduktor.

$\mathrm{ZnO}$ dengan ukuran skala nanometer dapat diaplikasikan sebagai fotodegradasi metamitron (Xu et al., 2016), sebagai fotodegradasi senyawa metilen biru (Sanna et al., 2016) dan sebagai antibakteri jenis bakteri gram positif dan negatif (Zarrindokht dan Pegah, 2012). Keberhasilan dalam pembuatan nanopartikel ZnO yaitu harus mempertimbangkan beberapa faktor diantaranya adalah sumber basa, capping agent dan metode sintesis yang digunakan.

Sintesis nanopartikel $\mathrm{ZnO}$ dapat dilakukan dengan menggunakan berbagai metode kimia dan menghasilkan berbagai bentuk seperti nanobelts (Zheng et al., 2001), nanopagoda (Chang et al., 2009), tetrapods (Rackauskas et al., 2015). Selain itu, metode yang biasa digunakan dalam sintesis nanopartikel logam oksida adalah metode mekanik dengan menghasilkan ukuran partikel berukuran nano (Ahmad dan Zhu, 2011), metode spray pyrolysis dengan hasil SEM menunjukkan bentuk bulat dari bismut oksida (Chu et al., 2013), metode sonochemical juga berhasil digunakan dengan memanfaatkan gelombang ultrasonik yang berfrekuensi $>20 \mathrm{kHz}$ (Samanta et al., 2015), metode hydrothermal dengan memanfaatkan suhu rendah dibawah $150{ }^{\circ} \mathrm{C}$ (Umar et al.,
2012), dan metode sol-gel pada sintesis nanopartikel CdO menggunakan ekstrak biji Parkia speciosa Hassk (Permana dan Yulizar, 2016).

Selain metode, sintesis nanopartikel $\mathrm{ZnO}$ membutuhkan bahan kimia sebagai oksidator. Pernah dilakukan sintesis nanopartikel $\mathrm{ZnO}$ menggunakan sumber basa dan capping agent seperti heksamin (Maryanti et al., 2012) dan $\mathrm{NaOH}$ (Saragi et al., 2015). Heksamin dan $\mathrm{NaOH}$ merupakan zat yang berbahaya dan tidak ramah lingkungan. Untuk mengurangi bahan yang berbahaya tersebut, penelitian terbaru melaporkan bahwa sintesis nanopartikel $\mathrm{ZnO}$ dapat menggunakan pendekatan metode hijau (green synthesis) dengan memanfaatkan bahanbahan yang ramah lingkungan sebagai sumber basa dan capping agent alami seperti ekstrak daun Imperata cylindrica L (Saputra dan Yulizar, 2016), Sapindus rarak DC (Maryanti et al., 2014), Lemon juice (Hoan et al., 2019), Moringa oleifera (Elumalai et al., 2015), Aspalathus linearis (Diallo et al., 2015). Dari berbagai metode yang pernah dilakukan dalam sintesis nanopartikel $\mathrm{ZnO}$, metode green synthesis lebih menjajikan karena ramah lingkungan, proses sederhana dan bahan-bahannya mudah didapat. Salah satu penggunaan metode green synthesis yaitu melibatkan bahan-bahan alami seperti ekstrak pada tumbuhan.

Tin atau Ara (Ficus carica Linn) merupakan tumbuhan yang berasal dari asia barat. Tumbuhan ini menghasilkan buah yang dapat dimakan. Selain menghasilkan buah, daun tin juga memiliki manfaat sebagai obat tradisional yang dapat digunakan dalam penyembuhan penyakit. Beberapa senyawa kimia yang terkandung di dalam ekstrak daun tin yaitu rutin, taraxsterol ester, bergapten, dan tyrosine moisture. Selain itu, ekstrak daun tin juga mengandung beberapa metabolit sekunder seperti Alkaloid, Flavonoid, Tannin, dan Steroid (Ahmad et al., 2012).

Kelebiahan daun tin juga sangat mudah didapat dan hasil uji fitokimia ekstrak daun tin menghasilkan kadar antioksidan yang bagus pada pelarut air dengan nilai IC 50 sebesar 33005 $\mu \mathrm{g} / \mathrm{mL}$ (Agustina, 2017). Salah satu senyawa antioksidan yang terdapat pada ekstrak daun tin adalah alkaloid. Senyawa alkaloid memiliki gugus fungsi amina yang dapat berfungsi sebagai sumber basa (alkali) dalam pembentukan nanopartikel ZnO (Sari et al., 2017).

Keterbaruan pada penelitian ini yaitu belum pernah dilakukan sintesis nanopartikel $\mathrm{ZnO}$ menggunakan media ekstrak daun tin. Dengan adanya gugus fungsi amina pada ekstrak daun tin diharapkan dapat menjadi 
sumber basa sekaligus capping agent alami dalam sintesis nanopartikel ZnO. Pemanfaatan fraksi air ekstrak kasar daun tin dapat difungsikan sebagai media sekaligus metode green synthesis nanopartikel $\mathrm{ZnO}$.

\section{BAHAN DAN METODE}

\section{Bahan}

Sampel daun Tin (Ficus carica Linn) di dapat dari daerah Cimanggis, Depok. Prekursor yang digunakan adalah $\mathrm{Zn}\left(\mathrm{NO}_{3}\right)_{2} \cdot 4 \mathrm{H}_{2} \mathrm{O}$ (merck), Akuades.

\section{Metode}

a. Preparasi sampel ekstrak daun tin (Ficus carica $L$

Sebanyak $5 \mathrm{~g}$ serbuk daun tin segar yang sudah dikeringkan ditambahkan dengan $100 \mathrm{~mL}$ akuades. Campuran distirrer selama 1 jam pada suhu $70{ }^{\circ} \mathrm{C}$ sampai ekstrak berwarna coklat. Setelah itu, ekstrak yang didapat disaring dengan kertas Whatman No. 1.

\section{b. Green synthesis nanopartikel $\mathrm{ZnO}$}

Sebanyak $30 \mathrm{~mL}$ ekstrak daun tin ditambahkan dengan $5 \mathrm{~g} \mathrm{Zn}\left(\mathrm{NO}_{3}\right)_{2} \cdot 4 \mathrm{H}_{2} \mathrm{O}$ dan distirrer selama 24 jam pada suhu $85{ }^{\circ} \mathrm{C}$. Pasta yang didapatkan difurnace pada suhu $500{ }^{\circ} \mathrm{C}$ selama 4 jam.

\section{Karakterisasi}

Serbuk nanopartikel ZnO dikarakterisasi menggunakan instrumen UV-Vis (Shimadzu 2600) dan UV-Vis (Shimadzu 2450) pada panjang gelombang 200-800 nm. XRD (Shimadzu 610) pada sudut difraksi $20-80^{\circ}$ dengan kecepatan goniometer sebesar $0,6^{\circ} 2 \theta /$ menit pada interval $0,01^{0}$ digunakan untuk mengetahui kristalinitas yang terbentuk, FTIR (Shimadzu Prestige 21) berfungsi untuk analisis gugus fungsi pada ekstrak dan nanopartikel hasil sintesis pada bilangan gelombang 4000-400 $\mathrm{cm}^{-1}$, dan SEM-EDX (AMETEK) dengan voltage $20 \mathrm{kV}$, spot size 50 , work distance $10 \mathrm{~mm}$ untuk melihat bentuk morfologi nanopartikel ZnO. PSA dan PZC dengan sistem dynamic light scattering (DLS) untuk melihat distribusi ukuran partikel dan muatan partikel.

\section{HASIL DAN PEMBAHASAN}

Sintesis nanopartikel $\mathrm{ZnO}$ berhasil dilakukan dengan menggunakan media ekstrak daun tin (Ficus carica L). Proses pengeringan daun tin segar selama 7 hari berfungsi untuk mengurangi kadar air yang terkandung dalam daun tin. Ekstrak daun tin dan serbuk nanopartikel $\mathrm{ZnO}$ yang dihasilkan dikarakterisasi menggunakan UV-Vis dan UV-Vis DRS untuk mengetahui panjang gelombang maksimum dan nilai absorbansi. Gambar 1 menunjukkan hasil spektrum nanopartikel $\mathrm{ZnO}$ dan ekstrak daun tin menggunakan Spektrofotometer UV-Vis. Hasil pengukuran UV-Vis ekstrak daun tin didapatkan puncak serapan yang khas pada panjang gelombang maksimum $320 \mathrm{~nm}$ dan nilai absorbansi 0,8. Adanya puncak serapan pada ekstrak daun tin diprediksikan bahwa daun tin mengandung metabolit sekunder seperti alkaloid, flavonoid dan tannin.

Munculnya puncak serapan pada panjang gelombang maksimum $260 \mathrm{~nm}$ dan nilai absorbansi 0,6 menandakan nanopartikel $\mathrm{ZnO}$ terbentuk. Hasil ini sesuai dengan penelitian yang dilakukan oleh (Chikkanna et al., 2019). Munculnya pucak serapan pada panjang gelombang $260 \mathrm{~nm}$ diprediksikan bahwa nanopartikel ZnO memiliki fenomena SPR (surface plasmon resonance).

Setelah dilakukan perhitungan persen reflektan hasil UV-Vis DRS nanopartikel ZnO memiliki nilai band gap sebesar 3,32 eV pada panjang gelombang $353 \mathrm{~nm}$ (gambar 2).

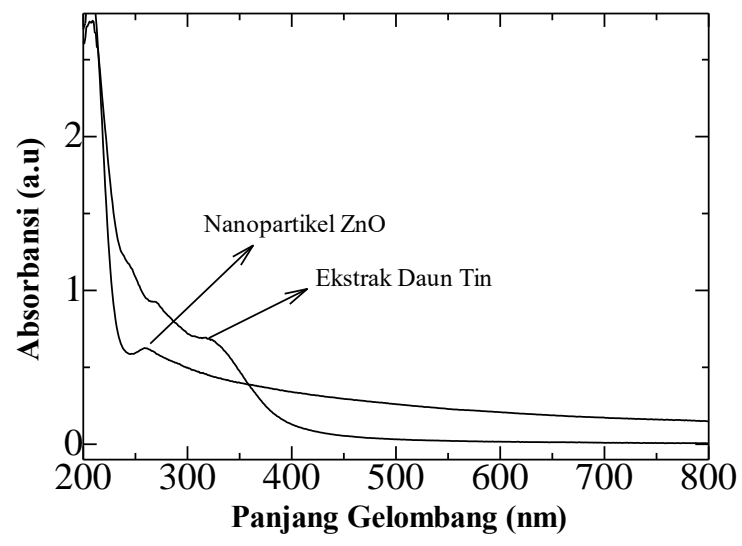

Gambar 1. Spektrum UV-Vis Nanopartikel ZnO

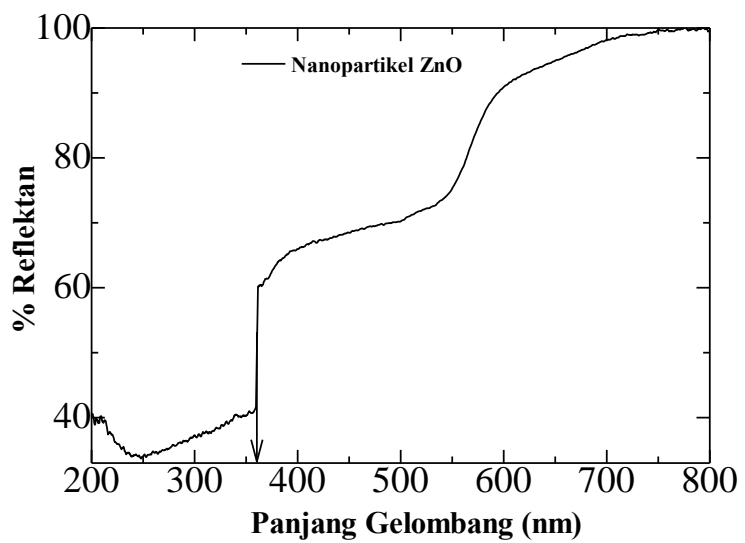

Gambar 2. Spektrum UV-Vis DRS Nanopartikel ZnO

Hasil XRD menunjukkan puncak kristalinitas yang khas nanopartikel $\mathrm{ZnO}$ pada 2 theta $20-80^{\circ}$. Pola difraksi kristal nanopartikel $\mathrm{ZnO}$ sesuai dengan nilai JCPDS nomor 89-1397. 
Gambar 3 menunjukkan hasil pengukuran XRD nanopartikel ZnO. Derajat kristalinitas nanopartikel $\mathrm{ZnO}$ muncul pada 2 theta: $30.71^{\circ}$, $33.36^{0}, 37.20^{\circ}, 45.50^{\circ}, 54.56^{\circ}, 60.84^{\circ}, 68.03^{\circ}$, dan $66.99^{\circ}$. Nilai $(\mathrm{h}, \mathrm{k}, \mathrm{l})$ kristal nanopartikel $\mathrm{ZnO}$ pada 2 tetha adalah (100), (002), (101), (102), (110), (103), (112), dan (201). Setelah dilakukan perhitungan menggunakan persamaan Scherer's didapatkan rata-rata ukuran kristalinitas nanopartikel $\mathrm{ZnO}$ sebesar $15,9 \mathrm{~nm}$.

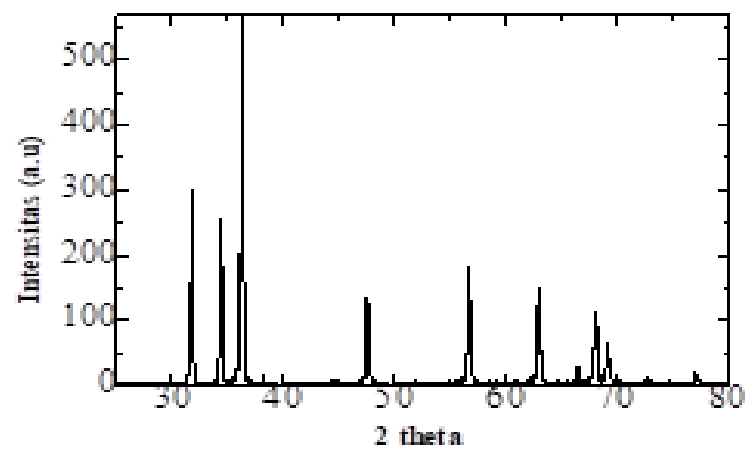

Gambar 3. Kristalinitas XRD Nanopartikel ZnO

Perbedaan ukuran kristal $\mathrm{ZnO}$ pada hasil pengukuran XRD dengan ukuran partikel pada hasil SEM sangat berbeda, hal ini dimungkinkan pada XRD memperlihatkan setiap unit-unit kristal dalam partikel sedangkan pada SEM memperlihatkan bentuk keseluruahan partikel $\mathrm{ZnO}$.

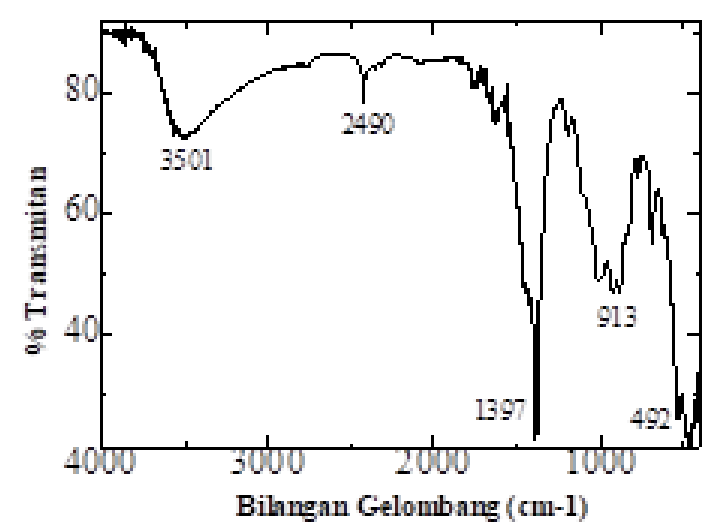

Gambar 4. Spektrum FTIR Nanopartikel ZnO

Gambar 4 menunjukkan spektrum hasil analisis menggunakan FTIR. FTIR berfungsi sebagai penentuan gugus fungsi pada ekstrak daun tin dan nanopartikel $\mathrm{ZnO}$ hasil green synthesis. Terdapat gugus fungsi yang aktif pada serbuk nanopartikel $\mathrm{ZnO}$ hasil sintesis menggunakan ekstrak daun tin seperti gugus hidroksil $(-\mathrm{OH})$ yang muncul pada bilangan gelombang $3501 \mathrm{~cm}^{-1}$, bilangan gelombang $2490 \mathrm{~cm}^{-1}$ menandakan adanya gugus $-\mathrm{C}=\mathrm{O}$, pada bilangan gelombang $1397 \mathrm{~cm}^{-1}$ menandakan adanya vibrasi stretching gugus fungsi $\mathrm{C}-\mathrm{O}-\mathrm{H}$ dengan mode bending, serapan gugus fungsi - $\mathrm{NH}$ (amina) terlihat pada bilangan gelombang $913 \mathrm{~cm}^{-1}$ dan keberhasilan terbentuknya nanopartikel ZnO terlihat puncak serapan pada bilangan gelombang $492 \mathrm{~cm}^{-1}$. Gugus amina pada ekstrak daun tin berperan penting sebagai sumber basa alami sehingga terbentuk $\mathrm{Zn}(\mathrm{OH})_{2}$ dan melalui proses kalsinasi terbentuk $\mathrm{ZnO}$.

Hasil pengukuran SEM-EDX menunjukkan bentuk partikel $\mathrm{ZnO}$ dan komposisi senyawa yang terkandung pada material tersebut. Gambar $5 a$ memperlihatkan bentuk partikel $\mathrm{ZnO}$ hasil sintesis menggunakan media ekstrak daun tin dan gambar 5b menunjukkan komposisi senyawa yang terlibat pada partikel $\mathrm{ZnO}$.

Nanopartikel ZnO memiliki bentuk partikel yang belum homogen (aglomerasi) dan seperti bentuk kapas yang terlihat pada perbesaran 2500 kali pada hasil SEM. Terjadinya aglomerasi pada nanopartikel $\mathrm{ZnO}$ dimungkinkan dari faktor pemberian ekstrak fraksi air daun tin yang terlalu banyak. Hasil EDX terlihat komponen yang tersusun adalah unsur $\mathrm{Zn}$ dengan kadar persen masa unsur sebesar $30,24 \%$ dan unsur $O$ sebesar 69,76\%. Persen komposisi ini merupakan jumlah total keseluruhan material ZnO yang terbentuk sebesar $100 \%$.

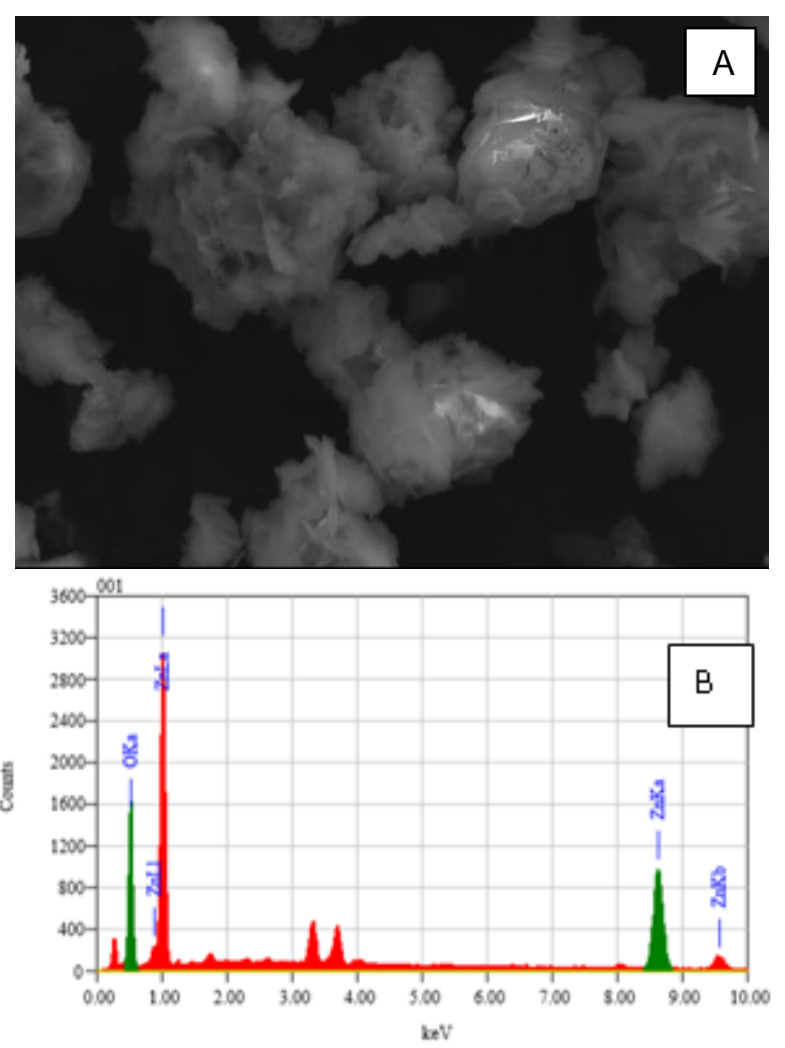

Gambar 5. (a) Gambar SEM dan (b) Komposisi EDX Nanopartikel ZnO

Penentuan intensitas muatan partikel, distribusi ukuran partikel dan nilai poli dispersi indeks (PDI) nanopartikel $\mathrm{ZnO}$ hasil dari sintesis menggunakan ekstrak daun tin dikarakterisasi menggunakan PSA (particle size analyzer) dan PZC (Potential Zeta Charge). 
Ukuran rata-rata distribusi nanopartikel $\mathrm{ZnO}$ adalah 49,62 nm dengan nilai PDI sebesar 0,739 (gambar 6). Ukuran distribusi partikel ZnO pada PSA lebih besar dibanding dari hasil karakterisasi menggunakan XRD. Hal ini karena pada pengukuran PSA semua komponen baik ukuran partikel pada ekstrak dan partikel $\mathrm{ZnO}$ terukur secara keseluruah sehingga ukuran menjadi besar.

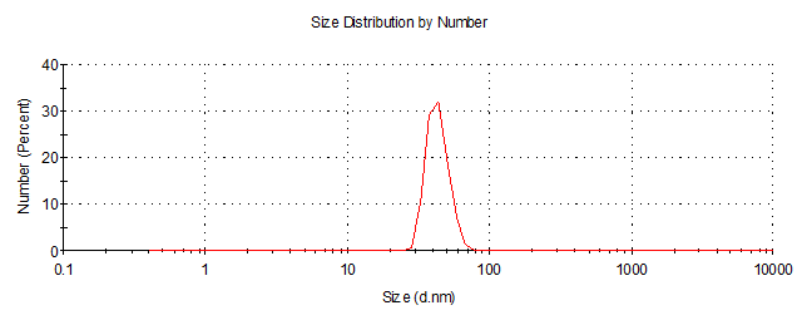

Gambar 6. Spektrum PSA Nanopartikel ZnO

Gambar 7 menunjukkan hasil analisa menggunakan zeta potensial. Nanopartikel ZnO memiliki gaya tolak-menolak sebesar $-23 \mathrm{mV}$. Hal ini mengindikasikan muatan (-) pada permukaan nanopartikel ZnO disebabkan adanya capping agent dari ekstrak daun tin.

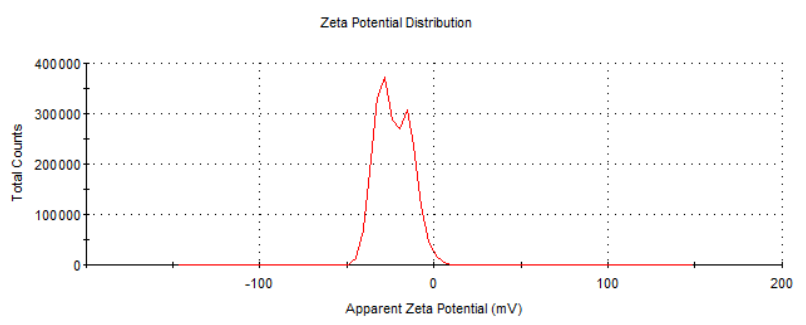

Gambar 7. Spektrum PZC Nanopartikel ZnO

\section{KESIMPULAN}

Ekstrak daun tin (Ficus carica $L$ ) berhasil dimanfaatkan sebagai media dalam sintesis nanopartikel ZnO. Metode green synthesis menggunakan bahan yang ramah lingkungan dari ekstrak daun dapat bertindak sebagai oksidator dan capping agent nanopartikel $\mathrm{ZnO}$. Proses hidrolisis menunjukan absorbsi nanopartikel $\mathrm{ZnO}$ terlihat pada panjang gelombang maksimum $260 \mathrm{~nm}$ dan pada bilangan gelombang $492 \mathrm{~cm}^{-1}$. Nanopartikel ZnO memiliki rata-rata ukuran kristal sebesar 15,9 nm dengan bentuk partikel seperti kapas. Komposisi masa unsur $\mathrm{Zn}$ sebesar 30,24\% dan O sebesar $69,76 \%$. Nanopartikel ZnO memiliki nilai PDI sebesar 0,739 dan distribusi rata-rata ukuran partikel sebesar 49,62 dengan nilai zeta potensial $-23 \mathrm{mV}$.

\section{DAFTAR PUSTAKA}

Agustina, E. 2017. "Uji Aktivitas Senyawa Antioksidan Dari Ekstrak Daun Tiin (Ficus
Carica Linn) Dengan Pelarut Air, Metanol Dan Campuran Metanol-Air." Klorofil 1 (1): 38-47.

Ahmad, J., I. Khan, S. Khan, and D. Iqbal. 2012. "Evaluation of Antioxidant and Antimicrobial Activity of Ficus Carica Leaves: An In Vitro Approach." Journal of Plant Pathology \& Microbiology $04 \quad(01): \quad 1-4$. https://doi.org/10.4172/2157-7471.1000157.

Ahmad, M., and J. Zhu. 2011. "ZnO Based Advanced Functional Nanostructures: Synthesis, Properties and Applications." Journal of Materials Chemistry 21 (3): 599614. https://doi.org/10.1039/c0jm01645d.

Chang, Y., W. Yang, C. Chang, P. Hsu, and L. Chen. 2009. "Controlled Growth of $\mathrm{ZnO}$ Nanopagoda Arrays with Varied Lamination and Apex Angles." Crystal Growth and Desaign 9 (7): 3161-3167.

Chikkanna, M. M., S. E. Neelagund, and K. K. Rajashekarappa. 2019. "Green Synthesis of Zinc Oxide Nanoparticles (ZnO NPs) and Their Biological Activity." SN Applied Sciences $\quad 1 \quad$ (1): $1-10$. https://doi.org/10.1007/s42452-018-0095-7.

Chu, Y., G. J. Lee, C. Y. Chen, S. H. Ma, J. J. Wu, T. L. Horng, K. H. Chen, and J. H. Chen. 2013. "Preparation of Bismuth Oxide Photocatalyst and Its Application in WhiteLight LEDs." Journal of Nanomaterials 2013. https://doi.org/10.1155/2013/596324.

Diallo, A., B. D. Ngom, E. Park, and M. Maaza. 2015. "Green Synthesis of $\mathrm{ZnO}$ Nanoparticles by Aspalathus Linearis: Structural \& Optical Properties." Journal of Alloys and Compounds 646: 425-30. https://doi.org/10.1016/j.jallcom.2015.05.2.

Elumalai, K., S. Velmurugan, S. Ravi, V. Kathiravan, and S. Ashokkumar. 2015. "Green Synthesis of Zinc Oxide Nanoparticles Using Moringa Oleifera Leaf Extract and Evaluation of Its Antimicrobial Activity." Spectrochimica Acta - Part A: Molecular and Biomolecular Spectroscopy 143:15864.https://doi.org/10.1016/j.saa.201 5.02.011.

Hoan, B. T., P. D. Tam, and V. H. Pham. 2019. "Green Synthesis of Highly Luminescent Carbon Quantum Dots from Lemon Juice." Journal Nanotechnology2019.https://doi.org/10.115 5/2019/2852816.

Maryanti, E., N. Isnaini, and R. A. Hanum. 2012. "Sintesis dan Karakterisasi Nanopartikel $\mathrm{ZnO}$ Terdoping Sulfur (ZnO:S) Melalui Metode Hidrotermal Suhu Rendah." Jurnal Gradien 8 (2): 815-818.

Maryanti, E., D. Damayanti, I. Gustian, and S. Yudha S. 2014. "Synthesis of ZnO Nanoparticles by Hydrothermal Method in Aqueous Rinds Extracts of Sapindus Rarak 
DC." Materials Letters 118: 9698.https://doi.org/10.1016/j.matlet.2013.

Parra, M. R., and F. Z. Haque. 2014. "Aqueous Chemical Route Synthesis and the Effect of Calcination Temperature on the Structural and Optical Properties of $\mathrm{ZnO}$ Nanoparticles." Journal of Materials Research and Technology 3 (4): 363-69. https://doi.org/10.1016/j.jmrt.2014.07.001.

Permana, Y. N., and Y. Yulizar. 2016. "Preface: International Conference on Recent Trends in Physics (ICRTP 2016)." Journal of Physics: Conference Series 755 (1). https://doi.org/10.1088/17426596/755/1/011 001.

Rackauskas, S., O. Klimova, H. Jiang, A. Nikitenko, K. A. Chernenko, S. D. Shandakov, E. I. Kauppinen, O. V. Tolochko, and A. G. Nasibulin. 2015. "A Novel Method for Continuous Synthesis of ZnO Tetrapods." Journal of Physical Chemistry C 119 (28): 16366-73. https://doi.org/10.1021/acs.jpcc.5b03702.

Samanta, P. K., A. Saha, and T. Kamilya. 2015. "Morphological and Optical Property of Spherical ZnO Nanoparticles." Optik 126 (18): 1740-43. https://doi.org/10.1016/j.ijleo.2015.04.025.

Sanna, V., N. Pala, V. Alzari, D. Nuvoli, and M. Carcelli. 2016. "ZnO Nanoparticles with High Degradation Efficiency of Organic Dyes under Sunlight Irradiation." Materials Letters 162: 257-60. https://doi.org/10.1016/j.matlet.2015.10.031

Saputra, I. S, and Y. Yulizar. 2016. "Preface: International Conference on Recent Trends in Physics (ICRTP 2016)." Journal of Physics: Conference Series 755 (1). https://doi.org/10.1088/17426596/755/1/011 001.
Saragi, T., M. Oktaviani, Y. R. Purba, S. A. Dhiya U, Risdiana, and A. Bahtiar. 2015. "Kontrol Ukuran Kristal Nanopartikel ZnO Yang Disintesis Dengan Metode Hidrotermal," Prosiding Pertemuan IImiah XXIX HFI Jateng \& DIY ISSN: 0853-0823.

Sari, R. N., Nurhasni, and M. A. Yaqin. 2017. "Sintesis Nanopartikel ZnO Ekstrak Sargassum Sp. Dan Karakteristik Produknya." JPHPI 20 (2): 238-54.

Umar, A., M. S. Akhtar, A. Al-Hajry, M. S. AlAssiri, and N. Y. Almehbad. 2012. "Hydrothermally Grown ZnO Nanoflowers for Environmental Remediation and Clean Energy Applications." Materials Research Bulletin $47 \quad$ (9): $2407-14$. https://doi.org/10.1016/j.materresbull.2012. 05.028.

Xu, Y., J. Jin, X. Li, Y. Han, H. Meng, T. Wang, and X. Zhang. 2016. "Simple Synthesis of ZnO Nanoflowers and Its Photocatalytic Performances toward the Photodegradation of Metamitron." Materials Research Bulletin 76:

235-39. https://doi.org/10.1016/j.materresbull.2015. 11.062.

Zarrindokht Emami-Karvani, and Pegah Chehrazi. 2012. "Antibacterial Activity of ZnO Nanoparticle on Gram-Positive and Gram-Negative Bacteria." African Journal of Microbiology Research 5 (18). https://doi.org/10.5897/ajmr10.159.

Zheng Wei Pan, Zu Rong Dai, and Zhong Lin Wang. 2001. "Nanobelts of Semiconducting Oxides." Science 291 (5510): 1947-49. https://doi.org/10.1126/science.1058120. 